\title{
LA DIGNIDAD DE LA PERSONA Y EL BLOQUE CONSTITUCIONAL DE DERECHOS
}

\author{
Humberto Nogueira Alcalá*1
}

RESUMEN: El autor afirma en su trabajo que la dignidad bumana es fundamento de los derechos fundamentales. Al mismo tiempo afirma que la misma constituye una limitación para la soberanía radicada en órganos estatales. Para ello, pasa revista a la Constitución chilena y a casi todos los textos latinoamericanos, proponiendo, en fin, un concepto de derechos fundamentales que permitan hacer operativo a favor de estos el bloque de constitucionalidad.

Palabras Clave: Dignidad - Derechos fundamentales - Constitución Política - Bloque de constitucionalidad.

\section{THE DIGNITY OF THE PERSON AND THE CONSTITUTIONAL BLOCK OF RIGHTS}

ABSTRACT: The author states in his work that the human dignity is the basis to the fundamental rights. At the same time, he states that this constitutes a limitation to the sovereignty that underlies the State organisms. For this, he goes through the Chilean Constitution and almost every Latinamerican textbook, to finally propose a concept of fundamental rights that allow the block of constitutionality to be operative favoring the former.

KEY wORDs: Dignity - Fundamental rights - Political Constitution - Constitutionality block.

SUMARIO: 1. La dignidad humana como fundamento de los derechos fundamentales, los cuales limitan la soberanía estatal. 2. Los derechos fundamentales. 2.1. La Constitución chilena utiliza los con-

Abogado. Doctor en Derecho por la Universidad Católica de Lovaina la Nueva (Bélgica). Profesor de Derecho Político y Constitucional, y Director del Centro de Estudios Constitucionales, Universidad de Talca. Correo electrónico: nogueira@utalca.cl

Artículo recibido el 12 de junio de 2006. Aprobado por el Comité Editorial el 26 de julio de 2006.

1 Clase Magistral de inauguración del año académico 2006 de la Escuela de Derecho de la Universidad Católica del Norte, sede Antofagasta. 
ceptos de "derechos" (artículo $1^{\circ}$, inciso $1^{\circ}$ ), "derechos esenciales que emanan de la naturaleza humana" (artículo $5^{\circ}$ inciso $2^{\circ}$ ), como asimismo de "derechos humanos" (artículo $9^{\circ}$ ), a su vez, se refiere a "derechos constitucionales" el encabezamiento del artículo 19. 2.1.1. El concepto de derechos constitucionales. 2.1,2. El concepto de derechos humanos. 2.1.3. Los derechos fundamentales como expresión genérica que incluye tanto los derechos constitucionales como los derechos humanos. 2.2. El bloque constitucional de derechos fundamentales. a) La doctrina del seguimiento nacional de la jurisprudencia emanada de las Cortes Supranacionales de Derechos Humanos. b) La doctrina del margen de apreciación nacional. 2.3. Los derechos fundamentales como derechos subjetivos y como componentes del orden constitucional objetivo. 2.4. Los derechos fundamentales como derechos subjetivos y como componentes del orden constitucional objetivo. 2.5. Los sujetos pasivos de los derechos fundamentales. Consideraciones finales.

\section{LA DIGNIDAD HUMANA COMO FUNDAMENTO DE LOS DERECHOS FUNDAMENTALES, LOS CUALES LIMITAN LA SOBERANÍA ESTATAL}

En el derecho constitucional latinoamericano la afirmación de la dignidad de la persona y de los derechos humanos como soporte del orden constitucional está presente en la mayoría de las Cartas Fundamentales ${ }^{2}$.

El artículo $1^{\circ}$, inciso $1^{\circ}$ de la Constitución chilena precisa: "Las personas nacen libres e iguales en dignidad y derechos".

La dignidad de la persona es el rasgo distintivo de los seres humanos respecto de los demás seres vivos, la que constituye a la persona como un fin en sí mismo, impidiendo que sea considerada un instrumento o medio para otro fin, además de dotarlo de capacidad de autodeterminación y de realización del libre desarrollo de la personalidad.

Esta posición es extendida en América Latina, pudiendo establecerse como ejemplo la Constitución de Bolivia en su texto de 1995, en su artículo 6, precisa: "II. La dignidad y la libertad de la persona son inviolables. Respetarlas y protegerlas es deber primordial del Estado"; la Constitución de Brasil de 1988, artículo $1^{\circ}$ señala que la República Federal de Brasil tiene como fundamentos... "III la dignidad de la persona humana"; la Constitución de Colombia de 1991, artículo $1^{\circ}$, prescribe: "Colombia es un Estado social de derecho [...] fundado en el respeto de la dignidad humana, en el trabajo y la solidaridad de las personas que lo integran y en la prevalencia del interés general"; la Constitución Peruana de 1993, en su artículo $1^{\circ}$, señala "la defensa de la persona humana y el respeto de su dignidad son el fin supremo de la sociedad y el Estado"; la Constitución de Honduras de 1982, artículo $5^{\circ}$, precisa: "la persona humana es el fin supremo de la sociedad y del Estado. Todos tienen la obligación de respetarla y protegerla"; la Constitución de Guatemala de 1985 establece en su artículo $1^{\circ}$; "Protección de la persona. El Estado de Guatemala se organiza para proteger a la persona y a su familia; su fin supremo es la realización del bien común". 
Von Wintrich sostiene que la dignidad del "hombre, como ente ético-espiritual, puede, por su propia naturaleza, consciente y libremente, autodeterminarse, formarse y actuar sobre el mundo que lo rodea" 3 .

A su vez, González Pérez nos señalará que la dignidad es la categoría que corresponde al ser humano por estar dotado de inteligencia y voluntad, distinto y superior a todo lo creado, que establece un tratamiento en toda circunstancia concordante con la naturaleza humana ${ }^{4}$.

La dignidad de la persona se constituye en el valor supremo, columna vertebral básica de todo el ordenamiento constitucional y fuente de todos los derechos fundamentales. Podemos sostener así la primacía de la dignidad de la persona sobre los derechos fundamentales, ya que estos tienen su fuente y fundamento en la primera, debiendo rechazarse el ejercicio de cualquier derecho que suponga un atentado a ella. La dignidad de la persona constituye una barrera insuperable en el ejercicio de los derechos fundamentales. La dignidad humana se constituye en una barrera o límite inmanente a toda reforma constitucional, que pretenda desconocerla, suprimirla, degradarla o desnaturalizarla. La dignidad del ser humano es el mínimum invulnerable que todo ordenamiento y operador jurídico debe asegurar y garantizar, sin que nunca pueda legitimarse un menosprecio del ser humano como persona digna.

La afirmación constitucional de la dignidad humana constituye un enunciado constitucional de eficacia directa y de aplicabilidad inmediata, teniendo un efecto anulatorio o invalidatorio de toda norma que contravenga o ignore dicha dignidad.

El artículo $1^{\circ}$, inciso $1^{\circ}$ de la Constitución, establece una norma directriz a través de la cual debe iluminarse e interpretarse todo el resto del texto constitucional y del ordenamiento jurídico nacional, constituye una pauta interpretativa que debe ser seguida por todos los operadores jurídicos, en cuanto norma rectora suprema de nuestro ordenamiento jurídico. Asimismo, como señala Ríos Álvarez, la dignidad de la persona tiene también el carácter de contenido integrador del vacío que puede llegar a producir la falta de reconocimiento o la omisión de un derecho indispensable o esencial a la preservación de la persona humana ${ }^{5}$.

Nuestro Tribunal Constitucional, en su sentencia sobre la "Unidad de análisis financiero y modificación del Código Penal en materia de

3 Von Wintrich, Zur Problematik der Grundrecte (1957), citado por Fernández SegaDO, Francisco: "La dignidad de la persona como valor supremo del ordenamiento jurídico español y como fuente de todos los derechos", en Revista Jus. Revista di Scienze Giuridiche, Anno L, Maggio-Agosto, 2003, Università Cattolica del Sacro Cuore, Milán, p. 205.

4 González PÉrez, J.: La dignidad de la persona, Civitas, Madrid, 1986, p. 112.

5 Ríos Álvarez, Lautaro: "La dignidad de la persona en el ordenamiento jurídico español", en obra colectiva, XV Jornadas Chilenas de Derecho Público, Valparaíso, Universidad de Valparaíso, 1985, p. 205. 
lavados y blanqueo de activos", de octubre del año 2003, ha establecido sobre la materia: "Que en tal orden de ideas cabe recordar, primeramente, por ser base del sistema constitucional imperante en Chile, el artículo $1^{\circ}$ inciso primero de la Constitución, el cual dispone que "las personas nacen libres e iguales en derechos". Pues bien, la dignidad a la cual se alude es aquel principio capital de nuestro Código Supremo es la cualidad de ser bumano que lo bace acreedor siempre a un trato de respeto, porque ella es la fuente de los derechos esenciales $y$ de las garantías destinadas a obtener que sean resguardados" 6 .

Los ámbitos de la dignidad humana que deben asumirse aplicando la pauta normativa de nuestro artículo $1^{\circ}$, inciso $1^{\circ}$ de la Carta Fundamental, son las dimensiones ontológicas dadas por la racionalidad y libertad del ser humano (autodeterminación consciente y responsable de su propia vida), como asimismo la de carácter ético o deontológico constituidas por la autonomía y fin en sí mismo, no siendo la persona un medio o instrumento de nadie.

De la dignidad del ser humano emana la libertad y la igualdad como principios básicos que, a su vez, concretan los derechos humanos.

La autodeterminación del ser humano, de la persona, lleva al libre desarrollo de la personalidad, posibilitando el despliegue de sus capacidades psíquicas, morales, sociales, culturales y económicas, la búsqueda de los ideales de ser humano y de protagonista de la sociedad en que vive en un momento histórico determinado.

La dignidad humana es, asimismo, compartida como concepción antropológica filosófica y moral del humanismo cristiano y del humanismo laico, desde las concepciones liberales a los socialismos democráticos.

Obviamente, el orden material de valores que implica la dignidad humana, como asimismo la libertad e igualdad esencial de todos los seres humanos es considerado por la Constitución chilena como anteriores a ella misma, en la medida que el texto de la Carta Fundamental no crea dichos valores, sino que se limita a reconocerlos, asegurarlos y garantizarlos, su fundamento último se encuentra en la idea de ser humano que asume la cultura occidental.

La dignidad de la persona es la fuente y fundamento de los derechos a través de los cuales se funda el consenso de la sociedad y se legitima el Estado, además de las garantías básicas para el desarrollo de la República democrática y del Estado de Derecho.

La Corte Constitucional alemana ha precisado que el artículo $1^{\circ}$ de la Ley Fundamental de Bonn, conocido como intangibilidad de la dignidad humana, no puede ser modificado mediante una reforma

Sentencia del Tribunal Constitucional, Rol $\mathrm{N}^{\circ} 389$, de fecha veintiocho de octubre de 2003, considerando decimoséptimo. 
constitucional tal y como lo dispone el art. 79 inc. $3^{\circ}$ de la Ley Fundamental, dependerá ante todo de las circunstancias en las cuales se considere violada la dignidad humana.

El trato que afecta la dignidad humana, otorgada por el poder público al ser humano en cumplimiento de la ley, debe ser considerado como una minusvaloración de las garantías de que goza el ser humano por virtud de ser persona, y en ese sentido tiene también el carácter de un trato abyecto"7.

Conforme a tales consideraciones podemos sostener que ningún derecho puede considerarse como derecho fundamental si contradice la dignidad humana, esta constituye un límite intangible para cada uno y todos los derechos fundamentales. Tal perspectiva implica, como lo muestran ejemplos prácticos de jurisdicciones constitucionales de otros países, que la dignidad humana legitima límites sobre determinados derechos, como por ejemplo pueden ser los derechos patrimoniales. En efecto, solo a título ejemplar, el Tribunal Constitucional español ha entendido que "los valores constitucionales que conceden legitimidad al límite que la inembargabilidad impone al derecho del acreedor que se cumpla la sentencia firme que le reconoce el crédito se encuentran en el respeto a la dignidad humana, configurado como el primero de los fundamentos del orden político y de la paz social en el art. 10.1, a cuyo fin resulta razonable y congruente crear una esfera patrimonial intangible a la acción ejecutiva de los acreedores que coadyuve a que el deudor pueda mantener la posibilidad de una existencia digna"8.

\section{LOS DERECHOS FUNDAMENTALES}

El artículo $5^{\circ}$ inciso $2^{\circ}$ de la Constitución prescribe: "El ejercicio de la soberanía reconoce como limitación el respeto de los derechos esenciales que emanan de la naturaleza humana".

En nuestro sistema constitucional los derechos no están en las normas (internas o internacionales), "no se constituyen" en la norma positiva sino que ella solo los asegura, los respeta, los garantiza y los promueve, los derechos emanan de la dignidad humana. Los derechos tampoco se realizan en las normas, sino que ellos se concretan en la vigencia

BvF 1/69, 2 BvR 629/68 y 308/69, citada por SCHAwE, Jürgen: Cincuenta años de jurisprudencia del Tribunal Constitucional Federal Alemán, Montevideo, Ediciones Jurídicas Gustavo Ibáñez y KAS, 2003, p. 17.

8 Sentencia del TC Español 113/1989 de 22 de junio, fundamento jurídico 3, citada por Fernández Segado, Francisco (n. 3), p. 228. 
sociológica, la que demuestra la efectividad de los derechos. La norma positiva solo significa vigencia normonológica? .

Como sostenía Maritain, "se trata de establecer la existencia de derechos (...) inherentes al ser humano, anteriores y superiores a las legislaciones escritas y a los acuerdos entre los gobiernos, derechos que no le incumbe a la comunidad civil otorgar, sino el reconocer y sancionar como universalmente valederos, y que ninguna consideración de utilidad social podría, ni siquiera momentáneamente, abolir o autorizar su infracción" 10 .

La Constitución explicita un aseguramiento genérico a la existencia de derechos esenciales, lo que da lugar a un catálogo de derechos abiertos, ya que el constituyente reconoce sus eventuales limitaciones y está consciente del desarrollo progresivo de los derechos y garantías acorde a la naturaleza y necesidades esenciales del ser humano.

No es posible seguir sosteniendo a inicios del siglo XXI lo que señalaban autores de la segunda mitad del siglo XIX, como Gerber ${ }^{11}$ o Jellinek ${ }^{12}$, para los cuales los derechos subjetivos públicos no representan más que una autolimitación impuesta y siempre revocable por el propio Estado.

La dignidad de la persona y sus derechos fundamentales establecen los valores esenciales en que se cimenta el consenso de la sociedad y legitiman el Estado, además de las garantías básicas para el desarrollo de la República democrática y del Estado de Derecho.

La denominación utilizada de derechos "esenciales" o fundamentales, consideramos que explicita la prioridad axiológica y su esencialidad, respecto de la persona humana. Hay una sola fuente de la fundamentalidad de los derechos, su relación con la dignidad humana, ya que son expresión inmediata y positiva de la misma, constituyendo el núcleo básico irreductible e irrenunciable del estatus jurídico de la persona. Por otra parte, tal denominación denota el carácter fundamentador del orden jurídico y político de la convivencia en sociedad de tales derechos, constituyendo elementos básicos del ordenamiento jurídico.

El criterio de fundamentalidad de los derechos es esencialmente material o sustantivo, dice relación con la dignidad humana, la libertad y la igualdad que son su fuente y con los ámbitos que posibilitan la existencia y el desarrollo del ser humano, en un contexto histórico y

9 BidART CAMPos, Germán: La interpretación de los derechos humanos en la jurisdicción internacional e interna. En V Congreso Iberoamericano de Derecho Constitucional. Ed UNAM, México, 1998, p. 98.

10 Maritain, Jacques: Acerca de la filosofía de los derechos del hombre. Ed. Debate. Madrid, España, 1991, p. 116.

11 Gerber, K.F.: Über öffentliche Rechte, 1852.

12 JeLLINEK, Georg: Das system der subjektiven äffentlichen Rechte, 1892. 
cultural determinado, dentro de una sociedad política construida con su participación y a su medida.

Asumimos así la perspectiva que los derechos fundamentales se protegen por su importancia intrínseca, desechando la concepción de que ellos son fundamentales porque son protegidos. Los derechos fundamentales en cuanto tienen su fuente en la dignidad humana y en cuanto buscan el libre desarrollo de la persona, exigen del ordenamiento jurídico positivo su protección y garantía. De hecho, puede reconocerse la existencia de derechos fundamentales implícitos o de derechos que serán reconocidos en el futuro como tales, dadas nuevas realidades del desarrollo de la existencia humana y de nuevos contextos de las sociedades políticas futuras.

Como señala Ferrajoli, "Lo que no puede consentirse es la falacia realista de la reducción del derecho al hecho y la determinista de la identificación de lo que acontece con lo que no puede dejar de acontecer" 13 .

El nexo entre expectativas $y$ derechos garantizados no es de naturaleza empirica sino normativa, "La ausencia de garantías debe ser considerado como una indebida laguna que los poderes públicos internos e internacionales tienen la obligación de colmar"14, la cual puede ser superada por una interpretación integradora de los derechos y sus garantías.

2.1. La Constitución chilena utiliza los conceptos de "derechos" (artículo $1^{\circ}$, inciso $1^{\circ}$ ), "derechos esenciales que emanan de la naturaleza humana" (artículo $5^{\circ}$ inciso $2^{\circ}$ ), como asimismo de "derechos humanos" (artículo $9^{\circ}$ ), a su vez, se refiere a "derechos constitucionales" el encabezamiento del artículo 19

Dichos conceptos pueden ser considerados análogos o considerar que constituyen conceptos jurídicos diversos.

\subsubsection{El concepto de derechos constitucionales}

El concepto de derechos constitucionales se utiliza para referirse a los derechos asegurados en la Carta Fundamental de cada Estado en forma específica.

El profesor Cea Egaña señala que los derechos fundamentales son aquellos "derechos, libertades, igualdades o inviolabilidades que, desde la concepción, fluyen de la dignidad humana y que son intrínsecos de la naturaleza singularísima del titular de esa dignidad. Tales atributos,

Ferrajoli, Luigi: Derechos y garantias, op. cit., p. 65 .

Idem, p. 63. 
facultades o derechos públicos subjetivos son, y deben ser siempre, reconocidos y protegidos por el ordenamiento jurídico, permitiendo al titular exigir su cumplimiento con los deberes correlativos" 15 .

Sin embargo, en el ámbito americano, los derechos fundamentales no son únicamente los asegurados expresamente en el texto constitucional, ya que además se encuentran los derechos implícitos y los derechos contenidos en tratados internacionales ratificados y vigentes, además de las otras fuentes del derecho internacional como el ius cogens y el derecho consuetudinario internacional.

El concepto de derechos implícitos nos permite considerar que no es necesario que un derecho esté configurado expresamente en la Constitución formal o en el derecho internacional convencional para ser derecho esencial, humano o fundamental. Ellos pueden deducirse de valores, principios, fines y razones históricas que alimentan el derecho positivo constitucional e internacional. El sistema de derechos humanos pleno tiene carencias normativas e implicitudes que es necesario extraer de los valores y principios, pudiendo faltar normas de reconocimiento. El constitucionalismo democrático chileno y americano así lo reconocen.

El Tribunal Constitucional chileno, en sentencia Rol N ${ }^{\circ} 226$ de 30 de octubre de 1995 , considerando $25^{\circ}$, determina:

"...la doctrina como nuestra Constitución Política reconocen la existencia de derechos, aunque no estén consagrados en el texto constitucional, a menos que esta consagración implique una violación a las normas fundamentales.

"Esta última expresión significa que los bombres son titulares de derechos por ser tales, sin que sea menester que se aseguren constitucionalmente para que gocen de la protección constitucional".

En el mismo sentido, la Corte Constitucional de Colombia en sentencia 477/95, determina:

"De un lado, el artículo 29 inciso c), de la Convención Americana, nos permite comprender el efecto vinculante de otros derechos que, aun cuando no fueron expresamente recogidos por los pactos internacionales ratificados por Colombia, quedaron implícitamente garantizados en virtud de tal disposición.

La disposición contenida en el literal c) del artículo 29, establece de un lado la expresa probibición de excluir los derechos inherentes al ser bumano $y$, por otra parte, otorga un amplio sentido de interpretación de los derechos inherentes a la persona, tal significación permite considerar el derecho a la

15 Cea Egaña, José Luis: Derecho Constitucional chileno, Tomo I, Editorial de la Universidad Católica de Chile, Santiago, Chile, 2002, p. 221. 
identidad consagrado de manera implícita en todos los pactos o convenios de carácter internacional, y en consecuencia objeto de protección jurídica".

En Europa, el Tribunal Constitucional italiano, en sentencia $38 / 1973$ y luego en la 159/1973, incluyó como derechos inviolables algunos no considerados por el texto constitucional como eran el derecho a la dignidad, el derecho al honor, el derecho a la intimidad, el derecho a la reputación, entre otros, que derivarán indirectamente de otras normas constitucionales y de los artículos 8 y 10 de la Convención Europea de Derechos Humanos, como del artículo $2^{\circ}$ de la Constitución italiana.

A su vez, como señala T. Ohlinger, "el Tribunal Federal suizo define en gran medida lo que quiere proteger como derechos constitucionales. Derechos fundamentales centrales como la libertad individual, la libertad de opinión, el derecho a ser escuchado y la prohibición de la arbitrariedad no figuran en el texto de la Constitución federal suiza, pero son reconocidos por el Tribunal federal como derechos constitucionales no escritos" 16 .

El Consejo Constitucional francés ha reconocido como derechos fundamentales no considerados en el texto constitucional al derecho a la libertad de contraer matrimonio (CC 97-389 DC) y el derecho a desarrollar una vida familiar normal (decisión del 13 de agosto de 1993), el derecho de asilo y los derechos de defensa en el proceso (CC 93-325 DC), la libertad de pensamiento y de expresión (CC 94-345 DC, 29 de julio de 1994), entre otros.

Ello exige al intérprete una tarea de delimitación y configuración de los derechos fundamentales considerando la fuente interna y la fuente internacional que los aseguran, como asimismo, considerando la jurisprudencia de las Cortes supra o internacionales cuya jurisdicción es obligatoria y vinculante para el Estado, ya que este último en cuanto tal y sus órganos tienen una obligación de resultado respecto de ella, aplicada de buena fe y en cumplimiento efectivo de las obligaciones internacionales asumidas por el Estado, los que constituyen límites a la interpretación del operador jurídico.

Para hacer evidente y otorgar seguridad jurídica en tal sentido, diversas constituciones europeas y latinoamericanas han establecido normas constitucionales que hacen imperativo este principio de interpretación de los derechos fundamentales, al efecto citaremos algunas de ellas a modo ejemplar:

16 Citado por Bon, Pierre, "La protección constitucional de los derechos fundamentales. Aspectos de Derecho Comparado Europeo", en Revista del Centro de Estudios Constitucionales, No 11, Madrid, España, 1992, p. 53. 
La Constitución argentina ya sostenía en su artículo 33, introducido por la reforma de 1860, que "las declaraciones, derechos y garantías que enumera la Constitución, no serán entendidos como negación de otros derechos y garantías no enumeradas; pero que nacen del principio de la soberanía del pueblo y de la forma republicana de gobierno".

La Constitución de Colombia, en su artículo 94, determina: " $\mathrm{La}$ enunciación de los derechos (...) no debe entenderse como negación de otros que, siendo inberentes a la persona bumana, no figuren expresamente en ellos".

La Constitución de Ecuador de 1998, en su artículo 19, señala: "Los derechos y garantías señalados en esta Constitución y en los instrumentos internacionales, no excluyen otros que se derivan de la naturaleza de la persona y que son necesarios para su pleno desenvolvimiento moral y material".

Una norma similar contiene la Constitución de Uruguay en su artículo 72, precisa: "La enumeración de derechos, deberes y garantías becha por la Constitución, no excluye los otros que son inherentes a la personalidad bumana o se derivan de la forma republicana de gobierno".

La Constitución de Venezuela de 1999, en su artículo 22, señala que "La enunciación de los derechos y garantías contenidas en esta Constitución $y$ en los instrumentos internacionales sobre derechos bumanos no debe entenderse como negación de otros que, siendo inberentes a la persona, no figuren expresamente en ellos. La falta de ley reglamentaria de estos derechos no menoscaba el ejercicio de los mismos".

Otras constituciones de América Latina que consideran la existencia de derechos implícitos son: Bolivia, art. 35; Brasil, art. $5 \mathrm{~N}^{\circ} 2$; Costa Rica, art. 74; Guatemala, art. 4; y Paraguay, art. 80.

Los derechos implícitos o no enumerados se desprenden también del artículo 29 de la Convención Americana de Derechos Humanos, literal c), la cual sostiene que "ninguna disposición de la presente Convención puede ser interpretada en el sentido de: c) Excluir otros derechos y garantías que son inberentes al ser bumano, o que se derivan de la forma democrática representativa de gobierno", y la disposición contenida en el artículo 29 de la Convención Americana en su literal c), permite comprender el efecto vinculante de otros derechos que, aun cuando no fueron recogidos expresamente por los pactos internacionales o por la Constitución, quedan implícitamente garantizados en virtud de la disposición analizada.

Las constituciones europeas no son ajenas a esta perspectiva, mencionaremos algunas a título ejemplar:

La Constitución alemana, en su artículo $1^{\circ}$, determina: "1. La dignidad del hombre es intangible, constituye deber de todas las autoridades del Estado su respeto y protección. 2. El pueblo alemán reconoce, en consecuencia, los derechos inviolables e inalienables del hombre como fundamento de toda comunidad bumana, de la paz y de la justicia en el mundo".

La Constitución española, en su artículo $10^{\circ}$, precisa: "La dignidad de la persona, los derechos inviolables que le son inherentes, el libre desarrollo 
de la personalidad, el respeto a la ley y a los derechos de los demás son fundamento del orden político y de la paz social".

La Constitución de Italia, en su artículo $2^{\circ}$, prescribe: "La República reconoce y garantiza los derechos inviolables del hombre, ora como individuo, ora en el seno de las formaciones sociales donde aquel desarrolla su personalidad".

La Constitución de Portugal, en su artículo 16, señala: "Los derechos fundamentales consagrados en la Constitución no excluyen cualquiera otros que consten en las leyes y las reglas aplicables de Derecho Internacional".

En tal sentido, es necesario tener presente también el artículo 29 de la Convención Americana de Derechos Humanos, que establece las normas de interpretación en materia de derechos.

El artículo 29, literal a), precisa que ninguna disposición de la Constitución, la Convención o las leyes deben ser interpretadas en el sentido que permitan al Estado suprimir el goce y ejercicio de los derechos y libertades reconocidas en la Convención o limitarlos en mayor medida que la prevista en ella.

La Convención establece un mínimo de contenido de los derechos que debe ser protegido por los Estados Parte, por lo que las disposiciones de la Convención no pueden ser interpretadas en el sentido de "limitar el goce y ejercicio de cualquier derecho o libertad que pueda estar reconocido de acuerdo con las leyes de cualquiera de los Estados parte o de acuerdo con otra Convención en que sea parte uno de dichos Estados". Ello exige al Estado parte y a sus operadores jurídicos aplicar el principio favor persona o favor bomine aplicando la norma que mejor protege u optimiza el derecho fundamental.

A su vez, la CADH, como lo señala el artículo 29, literal c), que constituye norma interpretativa imperativa para los Estados Partes precisa que no se pueden "excluir otros derechos y garantías que son inberentes al ser bumano o que se derivan de la forma democrática representativa de gobierno".

Esta norma constituye un reconocimiento explícito de la existencia de derechos implícitos, los cuales no pueden ser desconocidos por el solo hecho de no estar establecidos en una norma positiva.

Por otra parte, los ordenamientos constitucionales latinoamericanos han ido consolidando la perspectiva que los derechos fundamentales no son solo los derechos asegurados en el texto constitucional y los derechos implícitos, sino que una línea sostenida y consolidada ha sostenido que también lo son aquellos asegurados por los tratados internacionales ratificados y vigentes.

La Constitución chilena, reformada en 1989 , artículo $5^{\circ}$, inciso $2^{\circ}$ : "El ejercicio de la soberanía reconoce como limitación el respeto a los derechos esenciales que emanan de la naturaleza humana. Es deber de los órganos del Estado respetar y proveer tales derechos, garantizados 
por la Constitución, así como por los tratados internacionales ratificados por Chile y que se encuentren vigentes".

La reforma constitucional argentina de 1994, incorpora a la Carta Fundamental, en su artículo 75 , numeral 22, que establece las atribuciones del Congreso, la especificación de los tratados de derechos humanos con jerarquía constitucional. Ellos son: "la Declaración Americana de los Derechos y Deberes del Hombre, la Declaración Universal de Derechos Humanos; la Convención Americana sobre Derechos Humanos; el Pacto Internacional de Derechos Económicos Sociales y Culturales; el Pacto Internacional de Derechos Civiles y Políticos y su protocolo Facultativo; la Convención sobre la Prevención y la Sanción del delito de Genocidio; la Convención Internacional sobre Eliminación de Todas las Formas de Discriminación Racial; la Convención sobre la Eliminación de Todas las Formas de Discriminación contra la Mujer; la Convención contra la Tortura y otros Tratos o Penas crueles, Inhumanas o Degradantes; la Convención sobre los Derechos del Niño; en las condiciones de su vigencia, tienen jerarquía constitucional, no derogan artículos alguno de la Primera Parte de esta Constitución y deben entenderse complementarias de los derechos y garantías por ellos reconocidas. Solo podrán ser denunciados, en su caso por el Poder Ejecutivo Nacional, previa aprobación de las dos terceras partes de la totalidad de los miembros de cada Cámara".

"Los demás tratados y convenciones sobre derechos humanos, luego de ser aprobados por el Congreso, requerirán del voto de las dos terceras partes de la totalidad de los miembros de cada Cámara para gozar de la jerarquía constitucional".

La Constitución de Brasil de 1988, artículo 4, determina que "la República de Brasil se rige en sus relaciones internacionales por los siguientes principios: II.- Prevalencia de los Derechos Humanos". A su vez, el artículo 5 numeral $1^{\circ}$, ordena que las normas que definen "los derechos y garantías fundamentales tienen aplicación inmediata", como asimismo, que los derechos y garantías expresadas en la Constitución no excluyen otros resultantes del régimen y de los principios de ellas adoptados, o de los tratados internacionales en que Brasil sea parte.

La Constitución de Colombia de 1991, artículo 93, establece:

"Artículo 93.- Los tratados y convenios internacionales ratificados por el Congreso, que reconocen los derechos bumanos y que probíben su limitación en los estados de excepción, prevalecen en el orden interno".

La Constitución de Costa Rica, en su artículo 48, introducido por reforma del 18 de agosto de 1989, dispone "Toda persona tiene derecho al recurso de hábeas corpus para garantizar su libertad e integridad personales, $y$ al recurso de amparo para mantener o restablecer el goce de los otros derechos 
consagrados en esta Constitución, así como de los de carácter fundamental establecidos en los instrumentos internacionales sobre derechos bumanos, aplicables en la República. Ambos recursos serán de competencia de la Sala indicada en el Artículo 10".

La Constitución del Ecuador de 1998, en su artículo 18, precisa:

Artículo 18. - Los derechos y garantías determinados en esta Constitución y en los instrumentos internacionales vigentes, serán directa e inmediatamente aplicables por $y$ ante cualquier juez, tribunal o autoridad. En materia de derechos y garantías constitucionales, se estará a la interpretación que más favorezca su efectiva vigencia. Ninguna autoridad podrá exigir condiciones o requisitos no establecidos en la Constitución o la ley, para el ejercicio de estos derechos.

No podrá alegarse falta de ley para justificar la violación o desconocimiento de los derechos establecidos en esta Constitución, para desechar la acción por esos hechos, o para negar el reconocimiento de tales derechos.

Las leyes no podrán restringir el ejercicio de los derechos y garantías constitucionales.

La Constitución de Guatemala de 1985, en su artículo 46, establece el principio de que "en materia de derechos bumanos, los tratados y convenciones aceptados y ratificados por Guatemala, tienen preeminencia sobre el Derecho Interno".

La Carta Fundamental de Nicaragua de 1987, artículo 46, señala que se integran a la enumeración constitucional de derechos, aquellos consagrados en la Declaración Universal de Derechos Humanos; en la Declaración Americana de Derechos y Deberes del Hombre; el Pacto Internacional de Derechos Civiles y Políticos; el Pacto Internacional de Derechos Sociales Económicos y Culturales de Naciones; y en la Convención Americana de Derechos Humanos, con objeto de darles adecuada protección.

La Constitución de Venezuela de 1999, en su artículo 23, determina:

Artículo 23.- Los tratados, pactos y convenciones relativos a derechos humanos, suscritos y ratificados por Venezuela, tienen jerarquia constitucional y prevalecen en el orden interno, en la medida en que contengan normas sobre su goce y ejercicio más favorables a las establecidas por esta Constitución y la ley de la República, y son de aplicación inmediata y directa por los tribunales y demás órganos del Poder Público.

En el ámbito jurisprudencial pueden citarse solo a manera ejemplar algunas sentencias de jurisdicciones constitucionales latinoamericanas: 
La Corte Colombiana, en la sentencia C-225/95, determinó:

"el único sentido razonable que se puede conferir a la noción de prevalencia de los tratados de derechos bumanos y de derecho internacional bumanitario (CP 93 y $214 N^{\circ}$ 2) es que estos forman con el resto del texto constitucional un 'bloque de constitucionalidad', cuyo respeto se impone a la ley. En efecto, de esa manera se armoniza plenamente el principio de supremacía de la Constitución, como norma de normas (C.P. artículo $4^{\circ}$ ), con la prevalencia de los tratados ratificados por Colombia, que reconocen los derechos humanos y probíben su limitación en los estados de excepción (C.P.., artículo 93)" (Fundamento Jurídico $N^{o} 12$ ).

La Sala Constitucional de la Corte Suprema de Costa Rica, en sentencia V-282-90 del 13 de marzo de 1990 a las 17.00 hrs, determina:

"sin embargo, la previsión del artículo 8 de la CNACR no es innecesaria ni reiterativa, sino que constituye una garantía más para la protección de los derechos fundamentales de las personas menores de edad, En efecto, por medio de este precepto normativo se incorporan expresamente al ordenamiento interno las declaraciones de derechos de carácter supranacional; lo que vincula directamente al ordenamiento costarricense con tales declaraciones. De esta manera, los Tratados internacionales relativos a esta materia no son solo parte del ordenamiento interno; son, además, un patrón de interpretación de cualquier precepto, constitucional o legal, relativo al Código de la Niñez y la Adolescencia" 17 .

A su vez, la Sala Constitucional antes mencionada, en su fallo 3435 de 1992 y su aclaración N 5759-93 determina que "los instrumentos de derechos bumanos, vigentes en Costa Rica, tienen no solo un valor similar a la Constitución Política, sino que en la medida en que otorguen mayores derechos - garantías a las personas, priman por sobre la Constitución".

La Corte Constitucional de Guatemala ha determinado que los tratados de derechos humanos ingresan al orden jurídico interno con carácter de norma constitucional pero sin potestad reformatoria o derogatoria (sentencia de 19 de octubre de 1990, expediente $\mathrm{N}^{\circ} 280 / 90$, considerando VIII $)^{18}$.

17 Citada por Armıjo, Gilbert: "La tutela supraconstitucional de los Derechos Humanos en Costa Rica", en Revista Lus et Praxis, año $9 N^{\circ} 1$, Universidad de Talca, 2003, p. 51.

18 Ver Dulitzky, Ariel: "Los tratados de derechos humanos en el constitucionalismo iberoamericano", en Buergenthal, Thomas y Cançado Trindade, Antonio, Estudios Especializados de derechos bumanos. Tomo I, Inscituro Interamericano de Derechos Humanos, San José, Costa Rica, 1996, p. 158. 
Asimismo, el reconocimiento del carácter fundamental de los derechos y su carácter supraestatal, lo que reconocido por los Estados, lleva a estos a la obligación de respetar, garantizar y promover los derechos contenidos en las normas de derecho internacional vigentes en la materia, lo que significa la subordinación a los estándares mínimos previstos por el derecho internacional en la materia.

\subsubsection{El concepto de derechos bumanos}

En el contexto contemporáneo, se reserva generalmente para denominar a los derechos de la persona, reconocidos y garantizados por el Derecho Internacional, sea este Consuetudinario, Convencional o Ius Cogens (Derecho Internacional de los Derechos Humanos y Derecho Internacional Humanitario). Muchas veces el concepto se extiende a los presupuestos éticos y los componentes jurídicos positivados en las Cartas Fundamentales de cada Estado, denominados también derechos constitucionales o derechos fundamentales ${ }^{19}$.

El profesor Antonio Truyol y Serra escribe: "Decir que hay derechos humanos... equivale a afirmar que existen derechos fundamentales que el hombre posee por el hecho de ser hombre, por su propia naturaleza y dignidad; derechos que le son inherentes y que, lejos de nacer de una concesión de la sociedad política, han de ser por esta consagrados y garantizados" 20 .

Así Fernández Galiano podrá señalar que son "aquellos derechos de los que es titular el hombre no por graciosa concesión de las normas positivas, sino independientemente de ellas y por el mero hecho de ser hombre, de participar de la naturaleza humana"21.

Castán Tobeñas define los derechos del hombre "como aquellos derechos fundamentales de la persona humana -consideradas tanto en su aspecto individual como comunitario- que corresponden a este en razón de su propia naturaleza (de esencia a un mismo tiempo, corpórea, espiritual y social) y que deben ser reconocidos y respetados por todo poder o autoridad y toda norma jurídica positiva, cediendo, no obstante, en su ejercicio ante las exigencias del bien común"22.

19 Peces-Barba, Gregorio: Curso... op. cit., p. 37, y Cea Egaña, José Luis: Derecho Constitucional Chileno, Tomo I, p. 221. El profesor Costaricense Hernández Valle los define como el "conjunto de derechos y libertades jurídicas e institucionalmente reconocidos y garantizados por el Derecho Positivo".

20 Truyol y Serra, Antonio: En "Estudio Preliminar", a "los derechos humanos. Declaraciones y Convenciones internacionales", p, 11.

21 Fernández Galiano, Antonio: Derecho Natural. Introducción filosófica al derecho, p. 134.

22 Castán ToBeñas, José: Los derechos del bombre, pp. 13 y 14. 


\subsubsection{Los derechos fundamentales como expresión genérica que incluye tanto los derechos constitucionales como los derechos bumanos}

Al efecto, Peter Häberle señalará que los derechos fundamentales constituyen "el término genérico para los derechos humanos universales y los derechos de los ciudadanos nacionales"23.

A su vez, el profesor francés Louis Favoreu considera que por derechos fundamentales es necesario comprender "el conjunto de los derechos y libertades reconocidos a las personas físicas como a las personas morales (de derecho privado o de derecho público) en virtud de la Constitución pero también de los textos internacionales y protegidos tanto contra el poder ejecutivo como contra el poder legislativo por el juez constitucional o el juez internacional" 24 .

En este trabajo utilizaremos los conceptos de derechos fundamentales en esta última perspectiva, como derechos reconocidos jurídicamente a nivel nacional o internacional y que vinculan a las personas y a los Estados.

Los derechos fundamentales en una conceptualización afín con nuestra Carta Fundamental, son el conjunto de facultades e instituciones que, concretan las exigencias de la libertad, la igualdad y la seguridad bumanas en cuanto expresión de la dignidad de los seres bumanos -considerados tanto en su aspecto individual como comunitario-, en un contexto histórico determinado, las cuales deben ser aseguradas, respetadas, promovidas y garantizadas por los ordenamientos jurídicos a nivel nacional, supranacional e internacional, formando un verdadero subsistema dentro de estos.

La normativa jurídica constitucional latinoamericana no permite que el derecho constitucional y el derecho internacional de los derechos humanos sigan siendo considerados en forma compartimentalizada ${ }^{25}$, sino que deben ser abordados como fuentes de un único sistema de protección de los derechos que tiene por fundamento la dignidad de la persona humana, abordándolos en forma integral, realizando una tarea de armonización e integración, eliminando prejuicios y visiones conflictuales, otorgándoles una visión convergente y optimizadora de los derechos fundamentales.

El ámbito normativo de cada derecho fundamental está conformado por los elementos precisados tanto por la fuente normativa constitucional como por la del derecho internacional. El derecho constitucional

23 HäBERLE. Peter: "El concepto de los derechos fundamentales", en VV. AA.; Problemas actuales de los derechos fundamentales, Universidad Carlos III, Madrid, España, p. 94.

24 Favoreu, Louis: "Lélargissement de la saisine du Conseil constitutionnel aux jurisdictions administratives et judiciaires", RFDC No 4,1990, pp. 581 y siguientes. Traducción nuestra.

25 Cancado Trindade, Antonio: "Reflexiones sobre la interacción entre el Derecho Internacional y Derecho Interno en la protección de los Derechos Humanos", En AA. VV, $V$ Congreso Iberoamericano de Derecho Constitucional. México, UNAM, 1998, p. 109. 
queda así delimitado por los contenidos de ambas normativas, aplicando siempre aquella que mejor protege el derecho, dándole la mayor fuerza expansiva, que constituye una exigencia ínsita en los mismos derechos.

Como señala Bidart Campos: "La fuente interna y la internacional se retroalimentan. Los egoísmos interpretativos, cualquiera sea su origen y cualquiera el método que empleen para reducir el sistema en vez de procurar su ampliación y plenitud, no obedecen ni responden condignamente a la génesis y a la razón histórica del sistema de derechos, que nunca fue ni pudo ser -ni debe ser- de estrechez o angostamiento, sino de optimización en el marco histórico y situacional" 26 .

\subsection{El bloque constitucional de derechos fundamentales}

Por bloque constitucional de derechos fundamentales entendemos así el conjunto de derechos de la persona asegurados por fuente constitucional o por fuentes del derecho internacional de los derechos humanos (tanto el derecho convencional como el derecho consuetudinario y los principios de ius cogens) y los derechos implícitos, expresamente incorporados a nuestro ordenamiento jurídico por vía del artículo 29 literal c) de la $\mathrm{CADH}^{27}$, todos los cuales, en el ordenamiento constitucional chileno, constituyen límites a la soberanía, como lo especifica categóricamente el artículo $5^{\circ}$ inciso segundo de la Constitución chilena vigente ${ }^{28}$.

Este enfoque interpretativo de la Constitución y desde la Constitución, hecho en materia de derechos fundamentales, se complementa con el derecho internacional de los derechos humanos, el que viene de fuera pero se incorpora como fuente de derechos esenciales o fundamentales, complementando los que asegura directamente la Constitución, como lo establece explícitamente en Chile el artículo $5^{\circ}$ inciso $2^{\circ}$.

El bloque de derechos fundamentales que limita la soberanía no es una tabla cerrada, sino que se encuentra abierta al aseguramiento de nuevas exigencias esenciales de la persona humana.

El artículo 29, literal b), de la $\mathrm{CADH}$, exige aplicar al operador jurídico que se encuentra frente a diversas normas de derechos humanos o fundamentales aquella norma que mejor protege los derechos,

26 Bidart Campos, Germán: La interpretación de los derechos humanos, Buenos Aires, Ediar, 1998, pp. 30-31.

27 Dicha disposición establece lo siguiente: "Artículo 29. Normas de interpretación. Ninguna disposición de la presente Convención puede ser interpretada en el sentido de: C) Excluir otros derechos o garantías que son inherentes al ser humano o que se derivan de la forma democrática representativa de gobierno".

28 Sobre esta materia consultar Nogueira Alcal Á, Humberto: "Los derechos esenciales o humanos contenidos en los tratados internacionales y su ubicación en el ordenamiento jurídico nacional: doctrina y jurisprudencia", en Ius et Praxis, año $9 \mathrm{~N}^{\circ} 1$, pp. 403-466. 
aplicando la norma interna o la internacional, dependiendo de cuál sea aquella que optimice el goce y ejercicio del derecho.

Así puede sostenerse que tanto los derechos fundamentales contenidos en las normas constitucionales formales como los contenidos en los tratados internacionales constituyen un bloque en materia de derechos fundamentales de acuerdo con el cual deben ser interpretadas las leyes y demás normas infraconstitucionales.

El bloque de derechos fundamentales queda configurado por:

a) Los que la Carta Fundamental explicita sin taxatividad;

b) Los que asegura el derecho internacional a través de los principios de ius cogens ${ }^{29}$; los que asegura el derecho convencional internacional de derechos humanos y derecho humanitario ${ }^{30}$, y los que asegura el derecho internacional consetudinario.

c) Los derechos esenciales implícitos que puedan desarrollarse en el futuro, respecto de lo cuales no hay reconocimiento aún a través de las diversas fuentes del derecho interno o internacional.

El derecho constitucional exige a los agentes y órganos del Estado una función promocional, debiendo promover condiciones más humanas de vida y removiendo obstáculos para hacer efectivas la dignidad de la persona, la libertad y la igualdad, con miras a la plenitud del ejercicio de los derechos; función promocional reconocida, explícitamente, en nuestra Constitución, en el artículo $5^{\circ}$ inciso segundo ${ }^{31}$. Exige así la Constitución a todos los operadores jurídicos y, en especial, a los órganos de jurisdicción constitucional dentro sus competencias, remover los obstáculos que posibiliten el libre y pleno ejercicio de los derechos como asimismo maximizar el plexo de derechos y garantías de la persona humana.

El deber de promover los derechos también se concreta a través de una adecuada interpretación de ellos, ya que los derechos no son las normas, por tanto, cuando faltan normas debe producirse la integra-

29 Ellos han sido incorporados al derecho interno mediante la Convención de Viena sobre Derecho de los Tratados, ratificada por Chile y vigente desde 1981, cuyo artículo 53 determina: "una norma imperativa de derecho internacional general es una norma aceptada y reconocida por la comunidad internacional de Estados en su conjunto como norma que no admite acuerdo en contrario y que solo puede ser modificada por una norma ulterior de derecho internacional general que tenga el mismo carácter".

30 La Convención de Viena establece en el artículo 26: "Todo tratado en vigor obliga a las partes y debe ser cumplido por ellas de buena fe", y en el artículo 27: "Una parte no podrá invocar las disposiciones de su derecho interno como justificación del incumplimiento de un tratado",

31 El artículo $5^{\circ}$, inciso $2^{\circ}$, segunda oración, precisa: "Es deber de los órganos del Estado respetar y promover tales derechos, garantizados por esta Constitución, así como por los tratados internacionales ratificados por Chile y que se encuentran vigentes" (el destacado es nuestro). 
ción para suplir la falta de reconocimiento normonológico y no afirmar que porque no hay norma no hay derecho. El operador jurídico debe tener la flexibilidad de buscar una solución acorde con el espíritu del sistema de derechos, de acuerdo con su objeto y su finalidad, teniendo en consideración el contexto y la razón histórica, como asimismo los valores que explicita el sistema jurídico. Ello implica negar la posición reduccionista y mezquina para la protección de la persona y de sus derechos esenciales.

Nada impide, en una perspectiva técnico jurídica, la introducción de garantías de los derechos esenciales o humanos por vía de normas de derecho interno o provenientes del derecho internacional que constituyan un plus respecto de las normas vigentes, ya que ello cumple la finalidad de asegurar y de promover tales derechos que es un deber constitucional de todos los órganos y agentes estatales. La introducción de normas que mejoren el contenido de derechos y sus garantías no puede ser consideradas inconstitucionales, si se aplican las reglas interpretativas favor bomine y se tiene presente el desarrollo progresivo de los derechos.

Asimismo, si existe el postulado de la interpretación de las normas infraconstitucionales de conformidad con la Constitución como lo determina el artículo $6^{\circ}$ inciso primero de la Constitución, el cual precisa que "Los órganos del Estado deben someter su acción a la Constitución y a las normas dictadas conforme a ella", implica que los derechos esenciales contenidos en la Constitución formal y en los tratados internacionales limitan la soberanía como lo determina el artículo $5^{\circ}$ inciso $2^{\circ}$, de manera tal que este bloque constitucional de derechos constituye un parámetro conformador de la interpretación conforme a la Constitución, por lo que todas las normas infraconstitucionales deben interpretarse y aplicarse conforme al bloque constitucional de derechos ${ }^{32}$.

Los valores, principios y fines del capítulo de Bases de la Institucionalidad, en materia de derechos, son preceptos constitucionales directamente aplicables, a la luz de los cuales debe interpretarse todo el resto de la normativa constitucional y del ordenamiento jurídico, como lo ha explicitado el Tribunal Constitucional.

La labor interpretativa constitucional requiere de una reconstrucción de todo el contenido que establece el complejo normativo de la

32 En la misma perspectiva, el Comisionado Jaime Guzmán en la COMIsión DE Estudios DE

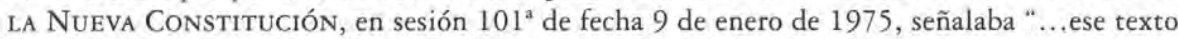
(refiriéndose al inciso $2^{\circ}$ del artículo $5^{\circ}$ ) autoriza entablar incluso recursos de inaplicabilidad y a pedir la inconstitucionalidad de leyes que aunque no violenten algún texto expreso de la Constitución, violenten derechos fundamentales de la persona humana, porque al hacerlo están violentando el texto expreso de la Constitución: el que señala que la soberanía está limitada por los derechos fundamentales o naturales del hombre" (p. 12). 
Constitución, la lectura e interpretación de todo precepto de la Carta Fundamental debe ser hecho en su contexto, teniendo en consideración los principios, valores, fines y razón histórica del ordenamiento constitucional, lo que le da al Juez Constitucional, un espacio significativo de movilidad interpretativa e integradora que convierte al juez en un protagonista activo y creador, que realiza la mediación entre la Constitución y la situación específica.

En materia de derechos humanos, habrá solo interpretación cuando se señale que fuera de las normas no hay otros derechos, mientras que además de interpretación habrá integración, cuando consideremos que fuera de las normas sobre derechos, hay derechos que carecen de normas.

Es posible "proponer que cuando faltan normas sobre derechos y quien detecta esa ausencia o laguna normativa cree o valora que, pese al vacío normativo, hay derechos no formulados, la carencia se debe colmar a través de la integración, para cuya efectividad también es menester "interpretar" (encontrar el sentido) del sistema completo de derechos, en el que algunos constan en normas y otros carecen de ellas"33.

La interpretación integradora de la Constitución implica que el juez presta atención a los derechos explícitos, a los valores, principios, fines y razones históricas del ordenamiento constitucional, completando y dando plenitud al sistema de derechos.

A su vez, el carácter esencialmente abierto de las normas que configuran abstractamente los derechos esenciales de la persona, llevan a desarrollar una interpretación de la Carta Fundamental y de todo el ordenamiento jurídico sobre el que ella actúa, en el sentido de que permita obtener para los derechos el mayor grado de protección y efectividad, entendidos desde una perspectiva democrática.

La confluencia e integración en el sistema jurídico de los derechos, reconocidos por vía de fuente interna y de fuente internacional, obliga a unificar el criterio de interpretación del sistema de derechos humanos, dando coherencia a dicho sistema.

Esta visión interpretativa convergente de los derechos, los asegurados por la Constitución y los asegurados por el derecho convencional internacional, deriva necesariamente del artículo quinto inciso segundo

33 Bidart Campos, Germán: La interpretación del sistema de derechos bumanos, Ediar, Buenos Aires, Argentina, 1994 p. 58 . En el caso chileno, ello ha sido aceptado por el Tribunal Constitucional, en su sentencia Rol No 22 de 1995, en el que reconoció que si bien el texto literal constitucional del derecho a la libertad de información (art. $19 \mathrm{~N}^{\circ}$ 2) no lo contempla, el derecho a ser informado es un derecho constitucional. Asimismo, la jurisprudencia de los tribunales superiores ordinarios (Cortes de Apelaciones y Corte Suprema) en diversos fallos han reconocido el derecho a la propia imagen pese a no estar consignado en el texto constitucional como derecho fundamental. 
de la Carta Fundamental. De esta manera, el sistema de derechos tiene la fuerza para ser interpretado de la forma más adecuada a su optimización.

Las fuentes internas y las fuentes internacionales de derechos se retroalimentan, las interpretaciones reduccionistas van en contra del sentido y finalidad del sistema de derechos esenciales fijado por la Carta Fundamental, que es lograr la optimización y plenitud del sistema, acogiendo el ámbito que más enriquece y garantiza el ejercicio de los derechos, este es el deber ser existencial del Derecho, como diría Cossio.

Todas las normas sobre derechos fundamentales contenidas en nuestro ordenamiento jurídico deben ser interpretadas armónicamente con las respectivas fuentes normativas de derecho interno como las fuentes convencionales internacionales (que son, a la vez, derecho interno, ya que se han incorporado tales derechos por mandato del constituyente originario a nuestro orden jurídico, constituyendo límites a la soberanía), con las claves hermenéuticas del derecho de los derechos humanos y sus órganos de aplicación, en especial, en el ámbito regional americano, por la Corte Interamericana de Derechos Humanos.

el derecho internacional de los derechos humanos es fuente del derecho interno cuando contiene elementos que enriquecen al derecho interno, cuando agregan un plus al contenido normativo de los derechos delimitados y configurados en el derecho interno y viceversa, el sistema nacional de derecho enriquece al derecho internacional de derechos humanos, buscando siempre la integralidad maximizadora del sistema de derechos esenciales o humanos, todo lo que está reconocido en el artículo 29 de la Convención Americana de Derecho Humanos y en el artículo $5^{\circ}$ del Pacto Internacional de Derechos Civiles y Políticos.

El intérprete constitucional debe entender que existe una retroalimentación recíproca entre fuente interna y fuente internacional recepcionada internamente en materia de derechos fundamentales. En la misma perspectiva debe existir una retroalimentación entre el intérprete final del derecho interno y el intérprete final del derecho regional o internacional de derechos humanos, especialmente, de aquel que el Estado se ha comprometido a respetar y garantizar ante la comunidad internacional.

a) La doctrina del seguimiento nacional de la jurisprudencia emanada de Las Cortes supranacionales de derechos bumanos

En esta interpretación debe considerarse el principio de la buena fe y las obligaciones derivadas de los tratados que aseguran derechos fundamentales, la jurisprudencia emanada de las cortes internacionales o supranacionales a las que se les ha reconocido jurisdicción vinculante 
y obligatoria para el Estado, el cual junto a todos sus órganos deben cumplir tales sentencias. Así los operadores jurídicos nacionales tienen el deber de dar seguimiento a la jurisprudencia de los órganos jurisdiccionales internacionales o supranacionales, sin perjuicio del margen limitado de interpretación de que disponen los tribunales nacionales. Es lo que se ha denominado la doctrina del seguimiento de la jurisprudencia de las Cortes internacionales o supranacionales.

La doctrina del seguimiento nacional de la jurisprudencia de la Corte Interamericana de Derechos Humanos se basa en el cumplimiento de buena fe de las obligaciones emanadas para el Estado Parte de la Convención Americana y su Protocolo Complementario de reconocimiento de la jurisdicción vinculante de la Corte Interamericana, como asimismo de la obligación de cumplir los fallos de dicha Corte, de acuerdo a lo dispuesto en los artículos 67 y 68 de la Convención Americana de Derechos Humanos o Pacto de San José de Costa Rica y lo dispuesto en el artículo 27 y 46 de la Convención de Viena sobre derecho de los tratados que impide al Estado nacional alegar reglas de derecho interno para oponerse al cumplimiento de las obligaciones emanadas de los tratados.

Corresponde a los tribunales nacionales realizar una interpretación armonizante y de cumplimiento del derecho interno con las obligaciones provenientes del derecho internacional de los derechos humanos, estando en juego el honor y la seguridad del Estado en la materia.

La Corte Suprema Argentina es el primer tribunal supremo en América del Sur en haber asumido explícitamente este nuevo paradigma en los casos "Ekmedjian c. Sofovich" 34 y "Giroldi" 35 , al asumir que la interpretación y jurisprudencia de la Corte Interamericana de Derechos Humanos "debe servir de guía a los tribunales argentinos", como asimismo, realizar los mejores esfuerzos para cumplir las recomendaciones de la Comisión Interamericana de Derechos Humanos, el cual ha compartido el liderazgo en la materia con la Sala Cuarta de la Corte Suprema de Costa Rica, en el ámbito centroamericano, a lo cual se han sumado diversos otras Cortes Supremas y Tribunales Constitucionales en América Latina.

A su vez, el Tribunal Constitucional peruano ha precisado que la Cuarta Disposición Final y Transitoria de la Constitución, implica:

\footnotetext{
34 Revista Jurídica La Ley, Buenos Aires, Argentina, 1992-C-543. Citado por SAgüÉs, Néstor Pedro: "Las relaciones entre los tribunales internacionales y los tribunales nacionales en materia de Derechos Humanos. Experiencias recientes", en Ius et Praxis, año $9 \mathrm{~N}^{\circ} 1$, p. 214.

35 Revista Jurídica La Ley, Buenos Aires, Argentina, 1995-D-461. Citado por SAGüés (n. 35), p. 214.
} 
"una adhesión a la interpretación que, de los mismos (de los tratados sobre derechos humanos) hayan realizado los organos supranacionales de protección de los atributos inherentes al ser humano $y$, en particular, el realizado por la Corte Interamericana de Derechos Humanos, guardián último de los derecbos en la Región" (Exp. No 217-02-HC/TC) ${ }^{36}$.

El Tribunal Constitucional peruano por cierto también ha desarrollado un seguimiento de los pronunciamientos del Comité de Derechos Humanos de Naciones Unidas, como lo indica entre otras sentencias, el fallo $\mathrm{N}^{\circ}$ 0018-1996-AI/TC; como asimismo de los informes de la Comisión Interamericana de Derechos Humanos, como lo expresan entre otras sentencias, los Exp. No 0010-2002-AI/TC; 1091- 2002-HC/TC; 0791-2002HCI/TC y 1260-2002-HC/TC ${ }^{37}$.

La Corte Suprema de Costa Rica, en su Sala Constitucional, Sentencia 3435-95 del 19 de mayo de 1995 , en su considerando $6^{\circ}$, precisa: "Como lo ba reconocido la jurisprudencia de esta Sala, los instrumentos de derechos bumanos, tienen no solamente un valor similar a la Constitución Política, sino que en la medida en que otorguen mayores derechos o garantías a las personas priman sobre la Constitución".

Finalmente la Sala Constitucional de la Corte Suprema de Costa Rica, en la sentencia 9.685 del 1 de noviembre del año 2000 precisó: "todos los instrumentos internacionales sobre Derechos Humanos han sido elevados a rango constitucional, y por consiguiente estos deben ser incorporados en la interpretación de la Constitución..."38.

El Tribunal Constitucional del Ecuador también ha implementado la doctrina del seguimiento de la jurisprudencia de la Corte Interamericana de Derechos Humanos, a modo ejemplar puede citarse el fallo $N^{\circ}$ 002-2002-CC de 12 de febrero de 2003, en el cual aplicó la Convención Americana de Derechos Humanos y la jurisprudencia de la Corte Interamericana para determinar el correcto sentido y alcance del artículo 187 de la Carta Fundamental que establece la justicia militar para el juzgamiento de infracciones cometidas por miembros de las Fuerzas Armadas en el ejercicio de sus labores profesionales. Al respecto el Tribunal Constitucional sostuvo:

"Que tanto el artículo 187 del texto constitucional como su vigésimo séptima disposición transitoria deben ser interpretados en concordancia con la consagración de las garantías judiciales del debido proceso que contiene la misma Constitución ecuatoriana, que se han señalado en este fallo, y

\footnotetext{
36 Citada por CARPIo Marcos, Edgar: La interpretación de los derechos fundamentales, Lima, Palestra, 2004, p. 68.

37 - Idem, p. 142.

38 Citada por Armijo, Gilbert: "La tutela supraconstitucional de los Derechos Humanos en Costa Rica", en Ius et Praxis, año $9 \mathrm{~N}^{\circ} 1,2003$, p. 61.
} 
con las reconocidas en los instrumentos internacionales vigentes en materia de derechos humanos, de obligatoria aplicación para el Ecuador y, por tanto, de todos los órganos del Poder Público, incluyéndose, naturalmente, los que ejercen jurisdicción, tal como lo ordenan los artículos 17 y 18 de la Constitución.

"Que, el artículo 8.1 de la Convención Americana sobre Derechos Humanos, dentro de las garantías judiciales, establece que el juez o tribunal encargado de la sustanciación de cualquier acusación penal debe ser competente, independiente e imparcial, como elementos esenciales del debido proceso legal;

"Que, como lo ha señalado la Corte Interamericana de Derechos Humanos la jurisdicción militar ha sido establecida por diversas legislaciones con el fin de mantener el orden y la disciplina dentro de las fuerzas armadas. Inclusive, esta jurisdicción funcional reserva su aplicación a los militares que hayan incurrido en delito o falta dentro del ejercicio de sus funciones y bajo ciertas circunstancias', agregando el Alto tribunal que, 'cuando la justicia militar asume competencia sobre un asunto que debe conocer la justicia ordinaria, se ve afectado el derecho al juez natural y, a fortiori, el debido proceso, el cual, a su vez, encuéntrase íntimamente ligado al propio derecho de acceso a la justicia', por lo que el Estado no debe crear 'tribunales que no apliquen normas procesales debidamente establecidas para sustituir la jurisdicción que corresponda normalmente a los tribunales ordinarios" (Corte Interamericana de Derechos Humanos, Caso Castillo Petruzzi y otros, Sentencia de 30 de mayo de 1999 , Serie $C \mathrm{~N}^{\circ} 52$ ),

"Que, por lo expuesto, en virtud de los principios de imparcialidad e independencia que informan la administración de justicia, los delitos comunes, incluso los cometidos por miembros de la Fuerza Pública, deben ser juzgados por la justicia ordinaria" 39 .

En el ámbito europeo, ella es la regla general, incluso la Corte Constitucional alemana, que era la más refractaria en la materia, ha aceptado que la Corte Europea determine la línea en materia de derechos humanos mientras no se afecte el mínimo de derechos garantizada por la Constitución alemana.

Así todo el sistema de derechos debe ser interpretado de conformidad con el estándar mínimo exigido por los tratados de derechos bumanos del cual el Estado es Parte y sus órganos jurisdiccionales de aplicación.

Algunos Estados, tanto europeos como latinoamericanos, han asegurado constitucionalmente este postulado de interpretación de los derechos:

39 Citada por Morales Tobar, Marcos: "Derechos Humanos y los tratados que los contienen en el derecho constitucional y la jurisprudencia en el Ecuador", en Ius et Praxis, año 9 $N^{\circ} 1,2003$, pp. 104-105. 
La Constitución de Colombia de 1991, reformada en 2001, en su artículo 93, inciso $2^{\circ}$, precisa: "Los derechos y deberes consagrados en esta Carta, se interpretarán de conformidad con los tratados internacionales sobre derechos bumanos ratificados por Colombia".

La Constitución del Perú de 1993, en su IV disposición final y transitoria, dispone: "Cuarta. Las normas relativas a los derechos y a las libertades que la Constitución reconoce se interpretan de conformidad con la Declaración Universal de Derechos Humanos y con los tratados y acuerdos internacionales sobre las mismas materias ratificados por el Perú".

La Constitución de Portugal de 1976, artículo 16, prescribe: "2. Los preceptos constitucionales y legales relativos a los derechos fundamentales deben ser interpretados e integrados en armonía con la Declaración Universal de los Derechos Humanos".

La Constitución de España de 1978, artículo 10 N² , determina:

"2. Las normas relativas a los derechos fundamentales y a las libertades que la Constitución reconoce, se interpretarán de conformidad con la Declaración Universal de Derechos Humanos y los tratados y acuerdos internacionales sobre las mismas materias ratificados por España".

Sin embargo, los propios tribunales supranacionales o internacionales de derechos humanos dejan un margen de apreciación a los tribunales de la jurisdicción interna de cada Estado Parte.

\section{b) La doctrina del margen de apreciación nacional}

Esta doctrina implica que los tribunales internacionales o supranacionales, al interpretar un derecho humano o fundamental asegurado por un tratado o convención internacional o supranacional, deben tener en consideración las particularidades del Estado Parte donde debe considerarse el problema a resolver, permitiendo a los tribunales nacionales un cierto margen de apreciación.

La doctrina del margen de apreciación nacional fue desarrollado por la Comisión y la Corte Europea de Derechos Humanos ${ }^{40}$.

El ámbito tolerado de margen de apreciación por la jurisdicción supranacional o internacional a las jurisdicciones domésticas varía según las circunstancias, las materias y el contexto, como asimismo la existencia de estándares comunes en los Estados Partes de las respecti-

40 Ver GANSHOF VAN DER MEersch, Walter: "Le caractere 'autonome' des termes et la 'marge d'appréciation' des gouvernements dans l'interpretation de la Convention europeénne des droits de l'Homme", en AA.VV., Protection del droits de l'bomme: la dimension europeénne, Berlín, Ed. Franz Matscher-Herbert Petzold, 1996, p. 207. 
vas convenciones de derechos humanos, lo que amplia o disminuye el correspondiente margen de apreciación.

Como señala Sagüés, "la amplitud de dicho 'margen de apreciación como el acierto de su ejercicio por las autoridades y tribunales de un país, puede y debe estar sometido al control de la autoridad supranacional. Esto es una suerte de necesidad jurídica, ya que de no haberla, un país podría eximirse del respeto u observancia del derecho, alegando impunemente su "margen de apreciación nacional" 41 .

En efecto, la doctrina del margen nacional de apreciación no tolera cegueras ideológicas o paradigmas mentales incompatibles con el nivel de desarrollo ético y jurídico aceptado regionalmente o internacionalmente. En tal caso, la jurisdicción internacional o supranacional declarará violado el derecho humano y establecerá la responsabilidad internacional del Estado, por ello, cualquiera sea el órgano interno del Estado (actos administrativos, resoluciones judiciales, legislación o incluso el propio texto constitucional) que haya provocado con su acción u omisión tal responsabilidad.

La Corte Interamericana de Derechos Humanos ha hecho referencia a esta doctrina en algunas de sus resoluciones, a título de ejemplo, la Opinión Consultiva 4/84, en la cual el Estado de Costa Rica consulta sobre el principio de igualdad en las condiciones para adquirir la ciudadanía de un país. Al respecto, la Corte señaló que "se trata de valores que adquieren dimensiones concretas a la luz de la realidad a que están llamados a materializarse y que dejan un cierto margen de apreciación para la expresión que deben asumir en cada caso" 42 .

\subsection{Los derechos fundamentales como derechos subjetivos y como componentes del orden constitucional objetivo}

Los derechos esenciales, fundamentales o humanos, no solo otorgan facultades a las personas y un estatus jurídico en un ámbito de la existencia; ellos tienen también una significación objetiva, son, como lo sostiene Schneider, la conditio sine qua non del Estado constitucional democrático, ya que no pueden dejar de ser pensados sin que corra un riesgo inminente el Estado constitucional contemporáneo. Así, los

\footnotetext{
41 Sagüés, Néstor Pedro. 2003. "Las relaciones entre los Tribunales Internacionales y los tribunales Nacionales en materia de Derechos Humanos. Experiencias en Latinoamérica", en Ius et Praxis, año $9 \mathrm{~N}^{\circ} 1,2003$, p. 219.

42 Sobre la materia ver Ventura, Manuel y Zovatro, Daniel: La función consultiva de la Corte Interamericana de Derechos Humanos, Costa Rica, pp. 306-307.
} 
derechos cumplen también funciones estructurales de gran importancia para los principios conformadores de la Constitución ${ }^{43}$.

De esta forma, en el Estado constitucional democrático, los derechos operan como derechos de defensa frente al Estado y los individuos, salvaguardando la dignidad de la persona y, al mismo tiempo, se objetivizan operando como elementos del ordenamiento objetivo, incorporando un orden axiológico objetivo que, en su condición de decisiones constitucionales básicas, vale para todos los ámbitos del Derecho, proporcionando directrices e impulsos para la legislación, la administración y la jurisprudencia" 44 .

Los derechos esenciales o fundamentales constituyen preceptos directamente vinculantes y aplicables que configuran y dan forma y de modo esencial al Estado, siendo este un Estado instrumental al servicio de la dignidad y de los derechos de la persona humana y del bien común.

El Estado constitucional republicano democrático que determina el capítulo I de Bases de la Institucionalidad en Chile, implica que todo el Estado y sus diferentes organismos e instituciones se constituyen en función de la dignidad de la persona, el pleno desarrollo de sus derechos fundamentales y el bien común, además de una adecuada distribución de la potestad estatal en órganos y funciones diferenciados que actúan dentro de sus respectivas competencias y de acuerdo a las formalidades que los respectivos ordenamientos jurídicos establecen, como lo exigen los artículos $1^{\circ}$ y $4^{\circ}$ al $7^{\circ}$ de la Carta Fundamental.

En efecto el artículo $1^{\circ}$ inciso $4^{\circ}$ precisa que "El Estado está al servicio de la persona humana y su finalidad es promover el bien común, para lo cual debe contribuir a crear las condiciones sociales que permitan a todos y cada uno de los integrantes de la comunidad nacional su mayor realización espiritual y material posible, con pleno respeto a los derechos y garantías que esta Constitución establece".

El bien común o el orden público no pueden invocarse como "medios para suprimir un derecho garantizado en la Constitución o en el

43 Schneider, H.P.: "Peculiaridad y función de los Derechos fundamentales de un Estado constitucional democrático", en Revista de Estudios Politicos, N 7 (Nueva época), Madrid, España, 1979, p. 23.

44 Citada por Stern, Klaus: "El sistema de los derechos fundamentales en la RFA", en Revista del Centro de Estudios Constitucionales, $\mathrm{N}^{\circ} 1$, septiembre-diciembre, 1988, Madrid, España. El Tribunal Constitucional español ha afirmado que el Tribunal Constitucional español, los derechos sin perder su naturaleza subjetiva, son "elementos esenciales de un ordenamiento objetivo de la comunidad nacional, en cuanto este se configura como marco de una convivencia humana, justa y pacífica, plasmada históricamente en el Estado de Derecho y, más tarde, en el Estado Social de Derecho o el Estado Social y Democrático de Derecho". 
derecho internacional de los derechos humanos ratificado y vigente, ya que dichos conceptos tienen como componentes esenciales el respeto a la dignidad y los derechos humanos, además de que deben interpretarse de acuerdo a las justas exigencias de una sociedad democrática, teniendo en consideración -como ha sostenido la Corte Interamericana de Derechos Humanos- "el equilibrio entre los distintos intereses en juego y las necesidades de preservar el objeto y fin de la Convención Americana de Derechos Humanos (C.I.D.H. O.C. 5-1986, párrafo 67).

Como señala García de Enterría, la Constitución asegura una unidad del ordenamiento jurídico, esencialmente sobre la base de un orden de valores materiales expreso en ella y no sobre las simples reglas formales de producción de normas ${ }^{45}$.

\subsection{La titularidad de los derechos fundamentales}

Todas las personas son titulares de estos derechos, constituyendo un rasgo estructural de ellos, que comporta también el carácter inalienable e indisponible de los intereses sustanciales en que consisten. Al ser tales derechos inalienables e innegociables constituyen prerrogativas no contingentes $\mathrm{e}$ inalterables.

El constitucionalista y filósofo del derecho argentino, prematuramente fallecido, Carlos Santiago Nino, sostenía que "Siendo la propiedad de ser individuos humanos la circunstancia antecedente que sirve de condición suficiente de estos derechos, todos los hombres tienen un título igual a ellos (salvo que se sostuviera, como algunos partidarios de la esclavitud y del aborto han pensado, que la humanidad es una propiedad que puede presentarse en distintos grados)" 46 .

La titularidad de los derechos es independiente de la edad y de la capacidad jurídica de la persona, incluso el nasciturus es titular del derecho a la vida. La Convención Americana de Derechos Humanos en su artículo primero, párrafo segundo, determina que "Para los efectos de esta Convención, persona es todo ser humano. A su vez, el artículo cuarto, párrafo $1^{\circ}$, precisa "Toda persona tiene derecho a que se respete su vida. Este derecho está protegido por la ley y, en general, a partir del momento de la concepción. Nadie puede ser privado de la vida arbitrariamente".

45 García de Enterría, Eduardo: La Constitución como norma y el Tribunal Constitucional, Madrid, España, 1985, p. 97.

46 Nino, Carlos: Introducción al análisis del Derecho, Ed. Astrea, Buenos Aires, Argentina, 1980 , p. 417. 
Obviamente, el nasciturus y los menores de edad e incapaces deben ser representados para hacer valer sus derechos.

El aseguramiento del respeto de los derechos de las personas contemplado en nuestro artículo $19 \mathrm{~N}^{\circ} 1$ no solo se refiere a los seres humanos, sino también a las personas jurídicas de acuerdo a la naturaleza de estas, lo mismo ocurre con los derechos asegurados por el derecho convencional internacional de los derechos humanos.

Cabe señalar, finalmente, que no todos los derechos contenidos en el artículo 19 de la Constitución pueden ser ejercidos por todas las personas, por ejemplo hay ciertos derechos que solo pueden ejercer quienes son nacionales, de acuerdo con las restricciones que la Constitución, o el legislador autorizado por la Carta Fundamental establece, como es el caso del derecho de asociarse en partidos políticos (art. $19 \mathrm{~N}^{\circ} 15$, inciso $5^{\circ}$ ), para lo cual se requiere ser ciudadano, como asimismo, del derecho de admisión a las funciones públicas.

\subsection{Los sujetos pasivos de los derechos fundamentales}

Los sujetos pasivos frente al respeto de los derechos son tanto el Estado y sus órganos, las personas jurídicas públicas y privadas, como asimismo los seres humanos o personas naturales. El respeto a los derechos fundamentales, sin lugar a duda, constituye uno de los fundamentos de nuestro ordenamiento jurídico, y en la medida que tales derechos tienen su fuente y fundamento en la dignidad humana, cualquier vulneración de esta última o de un derecho fundamental producida por acción u omisión de cualquier persona, autoridad u órgano estatal, constituye una conducta inconstitucional, la que se encuentra privada de legitimidad, por lo cual deberá ser anulada y reparada a través de las acciones constitucionales y legales disponibles al efecto.

El enunciado normativo constitucional del inciso $2^{\circ}$ del artículo $5^{\circ}$ de la Constitución chilena precisa: "El ejercicio de la soberanía reconoce como limitación el respeto de los derechos esenciales que emanan de la naturaleza bumana. Es deber de los órganos del Estado respetar y promover tales derechos, garantizados por esta Constitución, así como por los tratados internacionales ratificados por Chile y que se encuentran vigentes".

El Tribunal Constitucional en la sentencia sobre el proyecto de ley que modifica la Ley General de Urbanismo y Construcciones, precisa: "resulta imperativo recordar lo preceptuado en el artículo $5^{\circ}$, inciso $2^{\circ}$ de la Constitución, porque allí se impone a todos los órganos estatales, comenzando con el legislador, la obligación de respetar y promover el ejercicio de los derechos fundamentales.... Pues bien, la sujeción de tales órganos a lo ordenado en aquel precepto es aún más categórica e ineludible si se tiene presente que se trata de una base del sistema institucional, cuyo vigor normativo se irradia, de manera directa e 
inmediata, a la Carta Fundamental entera y a toda la legislación complementaria" 47 .

Por otra parte, el Estado en cuanto tal, en cuanto persona jurídica de derecho internacional, es responsable y se encuentra obligado por el derecho internacional de los derechos humanos y el derecho internacional humanitario a asegurar y garantiza a las personas que se encuentren en su territorio jurisdiccional los derechos humanos.

En efecto, a manera solo ejemplar señalaremos el artículo $1^{\circ}$, párrafo primero, de la Convención Americana de Derechos Humanos, el cual determina: "Los Estados Partes de esta Convención se comprometen a respetar los derechos y libertades reconocidas en ella y a garantizar su libre y pleno ejercicio a toda persona que esté sujeta a su jurisdicción, sin discriminación alguna por motivos de raza, color, sexo, idioma, religión, opiniones políticas o de cualquier otra índole, origen nacional o social, posición económica, nacimiento o cualquier otra condición social".

Esta es la primera obligación que tienen todos los Estados Partes, la que implica que los derechos asegurados por la Convención son de carácter autoejecutables, salvo que su redacción indique lo contrario, ya que el instrumento jurídico establece una obligación y no una facultad para los Estados Partes, como lo ha señalado la jurisprudencia de la Corte Interamericana de Derechos Humanos.

La primera obligación del Estado es respetar los derechos asegurados por el derecho internacional de los derechos humanos, lo que significa el deber de abstenerse de interferir en su ejercicio. Además, como segunda obligación prevista en al artículo $1^{\circ}$ de la Convención, el Estado Parte tiene la obligación de garantizar los derechos, lo cual implica no una acción de abstención como en el caso anterior, sino una obligación positiva consistente en adoptar las medidas necesarias para el efectivo goce y ejercicio de los derechos fundamentales por las personas sometidas a la jurisdicción del Estado e impedir la interferencia de terceros $^{48}$.

Como ha señalado la Corte Interamericana de Derechos Humanos, "la segunda obligación de los Estados Partes en la C.A.D.H., es la de "garantizar" el libre y pleno ejercicio de los derechos reconocidos en la convención a toda persona sujeta a su jurisdicción. Esta obligación implica el deber de los Estados Partes de organizar todo el aparato gubernamental y, en general, todas las estructuras a través de los cuales se manifiesta el ejercicio

47 Sentencia del Tribunal Constitucional, Rol N ${ }^{\circ} 437$, de fecha veintiuno de abril de 2005 , considerando decimotercero.

48 Sobre la materia ver FAúndez Ledesma, Héctor: El sistema interamericano de protección de los Derechos Humanos. Tercera edición puesta al día. San José, Costa Rica. Ed. Instituto Interamericano de Derechos Humanos, 2004, p. 77 y siguientes. 
del poder público, de manera tal que sean capaces de asegurar jurídicamente el libre y pleno ejercicio de los derechos bumanos. Como consecuencia de esta obligación, los Estados deben prevenir, investigar y sancionar toda violación de los derechos reconocidos por la convención y procurar, además, el restablecimiento, si es posible, del derecho conculcado y, en su caso, la reparación de los daños producidos por la violación de los derechos humanos" 49 .

Estas obligaciones de los Estados Partes se complementa con aquella establecida por el artículo $2^{\circ}$ de la Convención, que es la de adecuar el ordenamiento jurídico nacional a las obligaciones asumidas de acuerdo a la Convención, al efecto, el texto de la Convención determina lo siguiente: "Si el ejercicio de los derechos y libertades mencionados en el artículo $1^{\circ}$ no estuvieren ya garantizados por disposiciones legislativas o de otro carácter, los Estados partes se comprometen a adoptar, con arreglo a los procedimientos constitucionales y a las disposiciones de esta Convención, las medidas legislativas o de otro carácter que fueren necesarias para hacer efectivos tales derechos y libertades".

La responsabilidad estatal se inicia al momento de la ratificación del respectivo instrumento internacional, si este se encuentra vigente, salvo que el propio convenio internacional establezca retroactividad y eficacia futura.

La vigencia espacial de las obligaciones contraídas por el Estado en materia de derechos fundamentales o humanos ante la comunidad internacional, se extiende a todo el ámbito donde el Estado Parte ejerce jurisdicción y no solo el territorio nacional determinado por sus fronteras, afectando a sus legaciones diplomáticas, sus navíos y aviones que circulan fuera del territorio nacional, como asimismo los territorios extranjeros ocupados sobre los cuales ejerce un control efectivo. La responsabilidad estatal se extiende incluso a las actuaciones ocurridas en un tercer Estado (efecto extraterritorial), ya que el Estado tiene la obligación de no exponer a personas a torturas o tratos degradantes o donde la persona pueda ser condenada a pena de muerte, la extradición a países en situaron de guerra civil, entre otros casos.

El Estado en cuanto tal es el responsable por cualquiera de las acciones $\mathrm{u}$ omisiones de sus órganos y autoridades que signifiquen violación de los derechos humanos, sean estos actos, decisiones de autoridades gubernamentales, regionales o locales, de resoluciones del Poder Legislativo o resoluciones de las jurisdicciones internas, normas jurídicas de rango constitucional, legal, administrativo o resoluciones de las jurisdicciones internas. Baste en esta materia señalar, a manera ejem-

49 Sentencia de la Corte Interamericana de Derechos Humanos, caso Godínez Cruz, Sentencia de fecha 20 de enero de 1989, Serie C, número 5, párrafo 166. 
plar, las sentencias de la Corte Interamericana de Derechos Humanos que obligó a Chile a modificar el artículo 19 N 12 de su Constitución, para eliminar la censura previa para adultos en materia cinematográfica $^{50}$. La sentencia Castillo Petruzzi, que obligó al Estado peruano a dejar sin efecto una sentencia de la jurisdicción militar suprema del país ${ }^{51}$, o la sentencia del Caso Tribunal Constitucional del Perú, que obligó al Estado a reponer en sus cargos a los Magistrados del Tribunal Constitucional depuestos por acusación constitucional aprobada por el Congreso unicameral durante el Gobierno de Fujimori ${ }^{52}$, o la sentencia del caso Barrios Altos que obligó al Estado peruano a dejar sin efecto la ley de amnistía dictada por el Parlamento ${ }^{53}$.

Asimismo, son sujetos pasivos de los derechos fundamentales las personas jurídicas y naturales frente a terceros en las relaciones entre particulares, lo que la doctrina alemana denomina Drittwirkung, siendo en algunos Estados nacionales de tal eficacia directa, y en otros indirecta, de acuerdo a sus respectivos ordenamientos jurídicos.

La eficacia horizontal de los derechos humanos se une a la eficiencia vertical otorgando plenitud de vigencia a los valores incorporados en los derechos fundamentales en todas las dimensiones del ordenamiento jurídico.

Esta eficacia vertical y horizontal de los derechos fundamentales otorga seguridad jurídica de tales derechos; impide el desarrollo de una doble ética en la sociedad, una en las relaciones con el Estado y otra para las relaciones entre particulares; todo ello considerando que muchas de las principales amenazas a los derechos no provienen solo del Estado, sino también, y principalmente, de los poderes económicos y sociales fácticos de la propia sociedad civil.

\section{CONSIDERACIONES FINALES}

Los obstáculos para una efectiva vigencia del sistema de derechos fundamentales, en ocasiones son más bien de falta de conocimiento y "cultura de los derechos" de los operadores jurídicos (abogados y jueces), producto de paradigmas mentales o bloqueos de aceptación de nuevas

\footnotetext{
50 Sentencia de la Corte Interamericana de Derechos Humanos, Caso "La última tentación de Cristo", Sentencia de fecha 5 de febrero de 2001. Serie C $N^{\circ} 71$.

51 Sentencia de la Corte Interamericana de Derechos Humanos, Caso Castillo Petruzzi y otros, Sentencia de 30 de mayo de 1999 , Serie C No52.

52 Sentencia de la Corte Interamericana de Derechos Humanos, Caso "Tribunal Constitucional vs Perú", Sentencia de fecha 31 de enero de 2001, Serie C N $^{\circ} 71$.

53 Sentencia de la Corte Interamericana de Derechos Humanos, Caso "Barrios Altos", Sentencia de fecha 14 de marzo de 2001 , Serie $C^{\circ} N^{\circ} 75$.
} 
perspectivas recepcionadas por el derecho constitucional de las últimas décadas.

Existe una responsabilidad muy grande de los operados jurídicos de dar efectividad a los derechos esenciales, superando antinomias, lagunas y concretando garantías de los derechos, además de generar y promover una cultura jurídica de los derechos, superando paradigmas mentales que constituyen parte de la primera mitad del siglo XX y que hoy se erigen como fantasmas sentados sobre su propia tumba.

\section{Bibliografía}

- Armijo, Gilbert: "La tutela supraconstitucional de los Derechos Humanos en Costa Rica", en Ius et Praxis, año $9 \mathrm{~N}^{\circ} 1,2003$.

- Bidart Campos, Germán: La interpretación de los derechos humanos en la jurisdicción internacional e interna. En $V$ Congreso Iberoamericano de Derecho Constitucional. Ed UNAM, México, 1998. Buenos Aires, Ediar, 1998. : La interpretación de los derechos bumanos, : La interpretación del sistema de derechos bumanos, Ediar, Buenos Aires, Argentina, 1994.

- Bon, Pierre, "La protección constitucional de los derechos fundamentales. Aspectos de Derecho Comparado Europeo", en Revista del Centro de Estudios Constitucionales, N ${ }^{\circ}$ 11, Madrid, España, 1992.

- Cançado Trindade, Antonio: "Reflexiones sobre la interacción entre el Derecho Internacional y Derecho Interno en la protección de los Derechos Humanos", En AA. VV., V Congreso Iberoamericano de Derecho Constitucional. México, UNAM, 1998.

- Carpio Marcos, Edgar: La interpretación de los derechos fundamentales, Lima, Palestra, 2004.

- Castán Tobeñas, José: Los derechos del hombre, $3^{a}$ edición, Ed. Reus, Madrid, España, 1985.

- Cea Egaña, José Luis: Derecho Constitucional chileno, Tomo I, Editorial de la Universidad Católica de Chile, Santiago, Chile, 2002.

- Comisión de Estudios de la Nueva Constitución, en sesión $101^{\text {a }}$ de fecha 9 de enero de 1975.

- Dulitzky, Ariel: "Los tratados de derechos humanos en el constitucionalismo iberoamericano", en Buergenthal, Thomas y Cançado Trindade, Antonio, Estudios Especializados de derechos humanos. Tomo I, Instituto Interamericano de Derechos Humanos, San José, Costa Rica, 1996.

- Faúndez Ledesma, Héctor: El sistema interamericano de protección de los Derechos Humanos, $3^{a}$ edición puesta al día. San José, 
Costa Rica, Ed. Instituto Interamericano de Derechos Humanos, 2004.

- Favoreu, Louis: "L'élargissement de la saisine du Conseil constitutionnel aux jurisdictions administratives et judiciaires ", RFDC $\mathrm{N}^{\circ} 4,1990$.

- Fernández Galiano, Antonio: Derecho Natural. Introducción filosófica al derech, CEURA, Madrid, 1988.

- Ganshof van Der Meersch, Walter: "Le caractere autonome' des termes et la 'marge d'appréciation' des gouvernements dans l'interpretation de la Convention europeénne des droits de l'Homme", en AA.VV., Protection del droits de l'homme: la dimension europeénne, Berlín, Ed Franz Matscher-Herbert Petzold, 1996.

- García de Enterría, Eduardo: La Constitución como norma y el Tribunal Constitucional, Madrid, España, 1985.

- Gerber, K.F.: Úber öffentliche Rechte, 1852.

- González Pérez, J.: La dignidad de la persona, Civitas, Madrid, 1986.

- Häberle. Peter: "El concepto de los derechos fundamentales", en VV. AA.: Problemas actuales de los derechos fundamentales, Universidad Carlos III, Madrid, España.

- JellineK, Georg: Das system der subjektiven äffentlichen Rechte, 1892.

- Maritain, Jacques: Acerca de la filosofía de los derechos del hombre, Ed. Debate, Madrid, España, 1991.

- Morales Tobar, Marcos: "Derechos Humanos y los tratados que los contienen en el derecho constitucional y la jurisprudencia en el Ecuador", en Ius et Praxis, año $9 \mathrm{~N}^{\circ} 1,2003$.

- Nino, Carlos: Introducción al análisis del Derecho, Ed. Astrea, Buenos Aires, Argentina, 1980.

- Nogueira Alcalá, Humberto: "Los derechos esenciales o humanos contenidos en los tratados internacionales y su ubicación en el ordenamiento jurídico nacional: doctrina y jurisprudencia", en I $u$ s et Praxis, año $9 \mathrm{~N}^{\circ} 1,2003$.

- Ríos Álvarez, Lautaro: "La dignidad de la persona en el ordenamiento jurídico español", en obra colectiva, XV Jornadas Chilenas de Derecho Público, Valparaíso, Universidad de Valparaíso, 1985.

- SAGÜÉs, Néstor Pedro: "Las relaciones entre los tribunales internacionales y los tribunales nacionales en materia de Derechos Humanos. Experiencias recientes", en Ius et Praxis, año $9 \mathrm{~N}^{\circ} 1,2003$. : "Las relaciones entre los Tribunales Internacionales y los Tribunales Nacionales en materia de Derechos Humanos. Experiencias en Latinoamérica", en Ius et Praxis, año 9 $\mathrm{N}^{\circ} 1,2003$. 
- Schawe, Jürgen: Cincuenta años de jurisprudencia del Tribunal Constitucional Federal Alemán, Montevideo, Ediciones Jurídicas Gustavo Ibáñez y KAS, 2003.

- Schneider, H.P.: "Peculiaridad y función de los Derechos fundamentales de un Estado constitucional democrático", en Revista de Estudios Políticos, $\mathrm{N}^{\circ} 7$ (Nueva época), Madrid, España, 1979.

- STERn, Klaus: "El sistema de los derechos fundamentales en la RFA", en Revista del Centro de Estudios Constitucionales, $\mathrm{N}^{\circ} 1$, septiembre-diciembre, 1988, Madrid.

- Truyol y Serra, Antonio: En "Estudio Preliminar", a Los derechos humanos. Declaraciones y Convenciones internacionales, Tecnos, Madrid, España, 1982.

- Ventura, Manuel y Zovatto, Daniel: La función consultiva de la Corte Interamericana de Derechos Humanos, Costa Rica.

- Von Wintrich, Zur Problematik der Grundrecte (1957), citado por Fernández Segado, Francisco: "La dignidad de la persona como valor supremo del ordenamiento jurídico español y como fuente de todos los derechos", en Revista Jus. Revista di Scienze Giuridiche, Anno L, Maggio-Agosto, 2003, Università Cattolica del Sacro Cuore, Milán. 